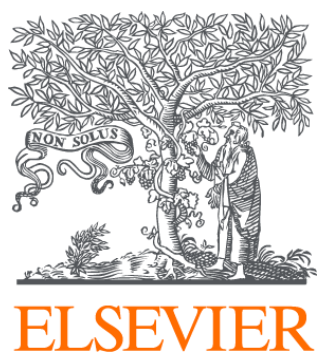

Since January 2020 Elsevier has created a COVID-19 resource centre with free information in English and Mandarin on the novel coronavirus COVID-

19. The COVID-19 resource centre is hosted on Elsevier Connect, the company's public news and information website.

Elsevier hereby grants permission to make all its COVID-19-related research that is available on the COVID-19 resource centre - including this research content - immediately available in PubMed Central and other publicly funded repositories, such as the WHO COVID database with rights for unrestricted research re-use and analyses in any form or by any means with acknowledgement of the original source. These permissions are granted for free by Elsevier for as long as the COVID-19 resource centre remains active. 


\section{Media watch}

\author{
Zoonoses: Infectious Diseases Transmissible \\ from Animals to Humans (3rd edn) \\ H Krauss, A Weber, M Appel, et al \\ ASM press, 2003 \\ US\$79.95, $464 \mathrm{pp}$ \\ ISBN 1555812368
}

With a background in both clinical medicine and veterinary medicine and current activity as an epidemiologist I regard any new publication on zoonoses with enthusiasm. There is a limited range of books devoted to the subject and many are now out of date.

The last paragraph of the introduction was much appreciated: "In the study of zoonoses, medical experts and veterinarians should cooperate closely to study the aetiology, epidemiology..."-that is an excellent mission statement.

I sought out severe acute respiratory syndrome coronavirus first-a recently described presumptive zoonosis and something I am working on presently. Next to see how influenza was covered, the other disease currently dominating my daily activities. They represent one novel and one erstwhile described condition and both accounts met with my approval, as did numerous other conditions that caught my eye. Indeed

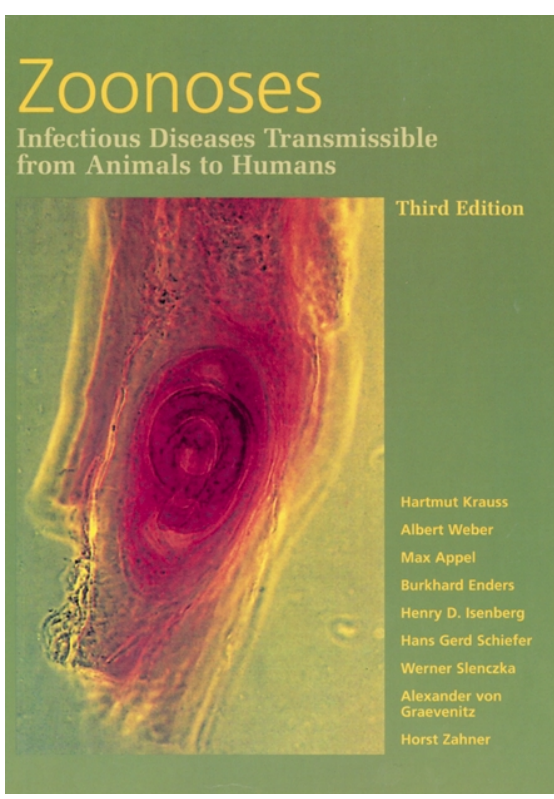

should find it an ample resource. From an infectious diseases specialist, epidemiological, or microbiology point of view it would serve as a breadth rather than depth reference.

Although it took a little longer than it should have, my belated discovery of the alphabetical order in the bacteria section was very helpful when navigating around, and obviated the need to refer to contents or index. Virus and parasite sections are grouped by family but it is not so easy to find a particular disease without consulting contents or index - for the virus section I do not understand the order logic. Additionally the "zoonoses caused by ..." is unnecessary in these two sections, as is the need to define the meaning of zoonoses in the title of the book.

Laboratory inclined colleagues may disagree but since I do not get too excited about PCR primers (virus section) I think these could be put in an appendix at the back. Such inclusion as an appendix does not mean I would not have much interest in it-I can affirm that I found the "animal bite infections" and "zoonoses involving various types of animals" appendices excellent resources. If I can be bold enough may I suggest "diseases by system" with a key to animal host involved in the next edition.

Overall, my final judgment of a book is by where it will reside on my after the initial "flick through" I had gained lots of new information, and a little embarrassment that I had told someone earlier in the day that Newcastle disease wasn't a zoonosis (thus my need for such a general reference).

After picking it up a few more times, I tried to ascertain which group would be most satisfied with this latest addition to the archives of zoonoses. I concluded that most clinicians bookshelves-those at the higher levels mostly gather dust; this one, I believe, will stay on the middle shelves until the fourth edition is produced. And it is certainly more portable than my "family bible", Zoonoses: Biology, Clinical Practice, and Public Health Control (Palmer SP, Soulsby EJL, Simpson DIH, et al, eds. Oxford; OUP; 1998).

Jeff Gilbert

\section{Technology and public health}

\section{Combating airborne pathogens}

A collaborative effort between chemists and engineers at the University of Buffalo (Buffalo, NY, USA) has yielded the BioBlower, a device that could swiftly destroy airborne pathogens in structures as large as the senate building in Washington, DC, which had to remain closed for several months after anthrax was detected there in 2001. The BioBlower has the potential to eradicate in minutes such pathogens as anthrax, smallpox, tuberculosis, and the severe acute respiratory syndrome coronavirus, according to its co-inventors.

The device works by rapidly heating contaminated air to temperatures above $200^{\circ} \mathrm{C}$, which effectively destroys pathogens in milliseconds, the developers say. In a series of tests, the team injected an aerosolised formulation of a benign anthrax simulant, Bacillus globicii, into the device and then recaptured the spores on the exhaust side to see if they were still alive. Most spores came through unscathed at temperatures below $200^{\circ} \mathrm{C}$; however, $99.9 \%$ were destroyed in a single pass, milliseconds after exposure to the heat (figure). The device could be used, for example, as a permanent part of a building's air-handling system to be activated immediately if biological pathogens were detected, or as a portable air-purification unit for first responders. It could also "sterilise" air in isolation units in hospitals.

The university has filed for a provisional patent on the device and is negotiating a licensing agreement with $\mathrm{B} 3$, the company that the developers formed to commercialise it. For wore information see http://www.buffalo.edu/news/fast-execute.cgi/articlepage.html?article $=65990009$ 


\section{Managing chemical and biological sensors}

The US Department of Energy's Oak Ridge National Laboratory in Tennessee is spearheading a public-private project that would enable real-time detection, identification, and assessment of chemical, biological, and radiological threats so that first responders could be dispatched within minutes of an event. Dubbed SensorNet, the system is being tested in Washington, DC, New York, and Tennessee. It works by strategically locating and connecting sensors on or at existing commercial and government facilities, and using telemetry to send critical information to incident management centers at local, state, and national levels simultaneously.

For more information see http://computing.ornl.gov/cse_home/ sensornet

\section{Collecting disease data in less developed countries}

The database company Voxiva has developed a system that enables health professionals in rural villages without computers to send disease information by a fixed telephone line, a cell phone, or a community public pay
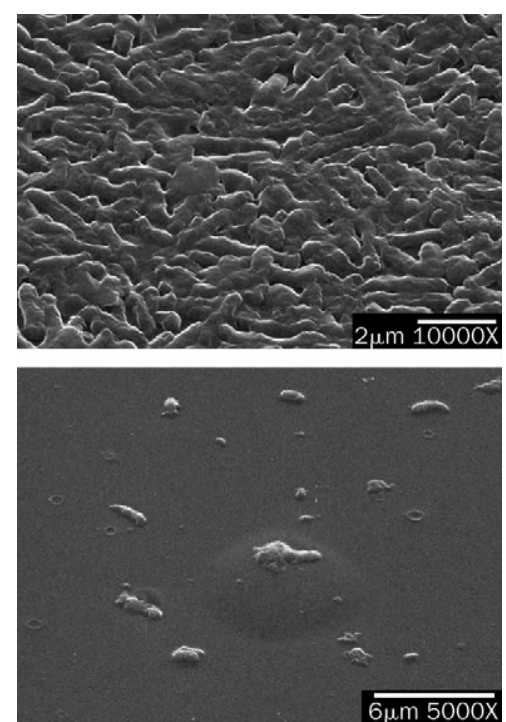

Scanning electron microscope image shows (top) sample teeming with viable spores of the anthrax simulant B globicii, and (bottom) dead residue of spores after passing through the BioBlower at $250^{\circ} \mathrm{C}$. system for health officials in Baghdad, Iraq, and an application that monitors US troops who receive the smallpox vaccine. Voxiva is also working on projects with the World Bank, Iraq's ministry of health, the US Agency for International Development, and the US Food and Drug Administration.

Voxiva founder Paul Meyer was recently named humanitarian of the year by the Massachusetts Institute of Technology publication Technology Review. for more information see http://www.voxiva.net

\section{Contacting sex partners by}

\section{email}

Health officials in Allegheny County, Pennsylvania, USA, like their colleagues in Los Angeles County and the San Francisco department of health in California, are using email to contact sex partners of people infected with sexually transmitted infections, according to an article in the Pittsburgh Post Gazette (http://www.post-gazette.com/pg/ 04069/283060.stm). The US Centers for Disease Control and Prevention is encouraging other health departments to consider email notification, and published an article on San Francisco's efforts in the February 20 issue of MMWR (http://www. cdc.gov/mmwr/preview/mmwrhtml/mm5306a4.htm). For more information see http://www.achd.net, http:// lapublichealth.org/aids/index.htm, and http://www. dph.sf.ca.us

Marilynn Larkin

MLEditor@aol.com 